\title{
Physicochemical Changes of Cocoa Beans during Roasting Process
}

\author{
Pedro García-Alamilla, ${ }^{1}$ Laura Mercedes Lagunes-Gálvez, ${ }^{1}$ \\ Juan Barajas-Fernández, ${ }^{2}$ and Ricardo García-Alamilla ${ }^{3}$ \\ ${ }^{1}$ Laboratorio de Ingeniería de Procesos, División Académica de Ciencias Agropecuarias (DACA), \\ Universidad Juárez Autónoma de Tabasco (UJAT), Carretera Villahermosa-Teapa Km. 25, La Huasteca, 86280 Centro, TAB, Mexico \\ ${ }^{2}$ División Académica de Ingeniería y Arquitectura (DAIA), Universidad Juárez Autónoma de Tabasco (UJAT), \\ Carretera Cunduacán-Jalpa de Méndez Km. 1, Col. La Esmeralda, Cunduacán, TAB, Mexico \\ ${ }^{3}$ Instituto Tecnológico de Ciudad Madero (ITCM), Juventino Rosas esq. Jesús Urueta, Col. Los Mangos, \\ 89440 Ciudad Madero, TAMPS, Mexico
}

Correspondence should be addressed to Pedro García-Alamilla; pedro.garciaa@ujat.mx

Received 2 March 2017; Revised 27 April 2017; Accepted 2 May 2017; Published 2 July 2017

Academic Editor: Ángel Calín-Sánchez

Copyright ( 2017 Pedro García-Alamilla et al. This is an open access article distributed under the Creative Commons Attribution License, which permits unrestricted use, distribution, and reproduction in any medium, provided the original work is properly cited.

\begin{abstract}
During cocoa beans roasting, there are physicochemical changes that develop the chocolate quality attributes. Roasting systems have a particular influence on the development of these characteristics, and the effects of operation variables for each system must be evaluated. The objective of this study was to evaluate the effect of roasting time and temperature in a rotatory system on cocoa beans physicochemical parameters of quality as moisture, water activity, $\mathrm{pH}$, total acidity, color $\left(L^{*}, a^{*}, b^{*}\right)$, total phenolic content (TPC), and DPPH radical capacity. Cocoa beans were roasted as a function with a central rotatable design with $2^{2}+5$ central points and 4 axial points $(-1.414,-1,0,+1$, and $+1,414)$ and a response surface methodology was applied. Temperature and time levels were $110-170^{\circ} \mathrm{C}$ and 5-65 minutes, respectively. The effect of the variables was nonlinear and modeled with a second-order response polynomial. Roasting time and temperature presented a significative effect $(p<0.05)$ on the response variables except for both TPC and DPPH radical capacity in aqueous extract.
\end{abstract}

\section{Introduction}

Cocoa beans (Theobroma cacao L.) roasting modifies the precursor compounds of flavor and aromas of origin, those formed during fermentation and drying (postharvest treatment). Roasting involves complex chemical transformations, attributed to Maillard reactions, caramelization of sugars, protein degradation, and synthesis of sulfur compounds [13]. During roasting, some compounds increase in concentration, the volatile fraction decreases, and new compounds are formed. Moisture loss and chemical reactions suffered by the beans in the roasting process affect the color, volume, mass, shape, bead pop, $\mathrm{pH}$, density, and especially volatile compounds and flavor $[4,5]$. Moreover, with the growing interest in the content of antioxidants in food and its relation to health, several products, including cocoa derivatives, have been investigated to determine their antioxidant properties and how the conditioning processes affect the content and antioxidant capacity thereof $[6,7]$. The antioxidant properties of cocoa promote consumption of their products, chocolates, and other derivatives. The postharvest and industrial processes have effect on the antioxidant content in cocoa. Roasting causes a high percentage of phenolic compounds and antioxidants which are destroyed by prolonged heating [8]. The cocoa industry uses two forms of management: whole cocoa beans and cotyledons (nibs) without shell. These forms of management differ in mass transport and energy during roasting [9].

There are different roasting methods that could be categorized as either batch or continuous modes, direct or indirect 
TABLE 1: Independent variables and their levels in central composite design.

\begin{tabular}{lccccc}
\hline Variables & \multicolumn{3}{c}{ Coded values } & & \\
& -1.414 & -1 & 0 & 1.414 \\
\hline Roasting temperature $\left({ }^{\circ} \mathrm{C}\right)$ & 110 & 120 & 130 & 140 \\
Roasting time $(\mathrm{min})$ & 5 & 14 & 30 & 46 & 55 \\
\hline
\end{tabular}

heating, and under dry or wet conditions. Since these roasting techniques were introduced to the chocolate industry, the roasting time and temperature have been studied. The results have showed data independently or contradictory to the standpoint of chemical characterization [9-11], which leads to the need of specific studies for the type of cocoa by region or roasting system. The solution is applying designs or models that allow for a proper assessment of the process. This study evaluated the effect of roasting time and temperature on the physicochemical characteristics of the cocoa bean produced in Tabasco, Mexico, in a rotary drum system by applying the surface response methodology.

\section{Materials and Methods}

This study was carried out with cocoa beans from Comercializadora Intercambio Mexicano de Comercio (IMCO) located in Cardenas City, Tabasco, Mexico, during the October 2015 cocoa season. The fermentation process was carried out with $1000 \mathrm{~kg}$ of raw cocoa, in wooden box $\left(1 \mathrm{~m}^{3}\right)$. Fermentation was carried out over 6 days and the cocoa mass was mixed by transferring it to another wooden box every $24 \mathrm{~h}$. Fermented cocoa beans were dried in a convective dryer called Samoa dryer. This dryer consists of a simple flue in a plenum chamber and a permeable drying platform above. After drying, the beans were cleaned and bagged. The cleaned sample consisted of whole beans and further a selection according to size homogenized to $1 \mathrm{~g}$ by particle. A sample of $100 \mathrm{~kg}$ of cocoa beans was selected for roasting tests.

Cocoa beans roasting was done in a rotary system roaster (Tostador Azteca $3 \mathrm{~kg}$ "http://mye100mex.com.mx"). The roaster consists of a rotating cylinder $(40 \mathrm{~cm}$ long and $33 \mathrm{~cm}$ wide), the envelope of which was heated by the combustion gas burned, and progressive heating took place until the selected temperature was reached. Constant rotation speed was at $30 \mathrm{rpm}$. The temperature was measured with thermocouples inside rotary system. An air extraction system immediately after the rotary cylinder using a centrifugal separator was used. Roasting time began since the moment that cocoa beans load entered the system.

2.1. Experimental Design. A central composite design (CCD) with two factors and axial points was used in this study. Each factor had three levels $(-1,0$, and +1$)$, which correspond to the low, middle, and high level. The factors and respective coded and uncoded levels are shown in Table 1. A total of 13 combinations were chosen in random order according to CCD. The dependent variables were moisture, water activity, instrumental color $\left(L^{*}, a^{*}, b^{*}\right)$, total phenolic content (TPC), and scavenging capacity of the DPPH radical. The effect of the independent variables on the responses $(Y)$ was modeled using a polynomial response surface:

$$
Y_{i}=\beta_{0}+\sum_{i=0}^{k} \beta_{i} X_{i}+\sum_{i<j}^{k} \beta_{i j} X_{i} X_{j}+\sum_{i}^{k} \beta_{i i} X_{i}^{2}+\varepsilon_{i},
$$

where $X_{i}$ are the independent variables, $\beta_{0}$ is the value of the fixed responses at the central point, and $\beta_{i}, \beta_{i j}, \beta_{i i}$ are linear, interaction, and quadratic coefficient, respectively. The polynomial model was used to evaluate the response variables to applying the analysis of variance (ANOVA), multiple regression analysis, and by analysis lack of fitness. Calculations were performed using the software MATLAB R2014a.

2.2. Preparation of Samples. The cocoa beans were roasted in batches of $2 \mathrm{~kg}$ according to experimental design (Table 1). The shell and germ were manually removed from the samples obtained after the roasting process and the cotyledons were ground and sieved through a standard mesh size number $20(850 \mu \mathrm{m})$ (Montinox "Manufacturado por Montiel inoxidable", Mexico). The powder obtained was used to carry out physicochemical analysis. In all cases, the measurements were performed in triplicate.

2.2.1. Moisture Determination. The samples $(1 \mathrm{~g})$ were fully dehydrated in an oven at $103^{\circ} \mathrm{C}$ for 24 hours. Their moisture content was calculated by weighing. The results were reported on dry matter.

2.2.2. Water Activity Determination $\left(a_{w}\right)$. Water activity was measured using a water activity meter to $25 \pm 1^{\circ} \mathrm{C}$ (AQUA LAB model CX2, DECAGON Devices).

2.2.3. Determination of Total Acidity Expressed through Free Acidity. Fifty milliliters $(50 \mathrm{ml})$ of distilled water was added to $5 \mathrm{~g}$ ground and sieved sample and stirred for an hour to homogenize, followed by potentiometric titration with $\mathrm{NaOH}(0.1 \mathrm{~N})(\mathrm{pH}$ of 8.3$)$. The results are expressed in milliliters of sodium hydroxide required to neutralize the free acid contained in one gram of cocoa beans $[10,11]$

$$
\text { Free acidity }=\frac{(V \mathrm{NaOH} 0.1 \mathrm{~N})}{5} .
$$

Zeller coefficient allows the calculation of the total acidity

$$
\text { Total acidity }=\text { Free acidity }\left(\frac{1}{0.5782}\right) .
$$


2.2.4. pH Measurement. Fifty milliliters $(50 \mathrm{ml})$ of distilled water was added to a sample of $5 \mathrm{~g}$ of ground and sieved beans and stirred for one hour to homogenize the mixture. The $\mathrm{pH}$ was determined using a potentiometer (Hanna Instrument $\mathrm{pH} 213)[12]$.

\subsubsection{Aqueous and Ethanolic Extract to Determine the Total} Phenolic Content (TPC). Extracts were prepared according to Singleton and Rossi method (1965), modified by Othman et al. [13]; either $4 \mathrm{ml}$ of distilled water or $4 \mathrm{ml}$ of ethanol (70\%) was added to $40 \mathrm{mg}$ of ground and sieved cocoa and stirred for 2 hours at $200 \mathrm{rpm}$ in an orbit shaker. The mixture was filtered through paper (Whatman Number 1) using a Buchner filtration unit. The filtrate was considered cocoa extract and used to determine TPC content.

2.2.6. Total Phenolic Content Determination. The TPC was prepared according to Othman et al. [13]. A $200 \mu \mathrm{L}$ aliquot was taken from the aqueous or ethanolic extract and $1.5 \mathrm{ml}$ of Folin-Ciocalteu reagent $\left(\mathrm{Hycel}^{\circledR}{ }^{\circledR}\right.$ added; after standing for $5 \mathrm{~min}, 1.5 \mathrm{ml}$ of $0.566 \mathrm{M} \mathrm{Na}_{2} \mathrm{CO}_{3}$ was added. The resulting mixture was incubated in a warm water bath for $20 \mathrm{~min}$ at $40^{\circ} \mathrm{C}$; then we proceeded to take the reading in a spectrophotometer at $725 \mathrm{~nm}$ (UV-Vis Genesys 10S, Thermo Scientific). The values were reported in equivalents of gallic acid (EAG). The calibration curve was performed in a range of 0.02 to $1.0 \mathrm{mg} \mathrm{ml}^{-1}$.

2.2.7. 2,2-Diphenyl-2-picrylhydrazyl Racial Scavenging Assay. The scavenging activity was estimated according to the method of Othman et al. [13]. An aliquot of cocoa extract $(200 \mu \mathrm{l})$ was mixed with $800 \mu \mathrm{l}$ of $100 \mathrm{mM}$ Tris- $\mathrm{HCl}$ to $\mathrm{pH} 7.4$ buffer. Then $1 \mathrm{ml}$ of DPPH $500 \mu \mathrm{M}$ was added. The mixture was shaked vigorously and left to stand for $20 \mathrm{~min}$ at room temperature in a dark room. Absorbance was read using a spectrophotometer at $517 \mathrm{~nm}$ (Genesys 10S Uv-Vis, Thermo Scientific). The scavenging effect of the DPPH radical was calculated using the following equation:

\section{Scavenging effect (\%)}

$$
=\left(1-\frac{\text { Absorbance of sample at } 517 \mathrm{~nm}}{\text { Absorbance of control at } 517 \mathrm{~nm}}\right) * 100 \text {. }
$$

2.2.8. Color Measurement. The color attributes $L^{*}, a^{*}, b^{*}$ of each sample were measured using a chromameter (IBM Modelo ColorTec PCM). The chromameter was calibrated against a white tile. The samples of cocoa beans cotyledons were measured for $L^{*}$ (lightness), $a^{*}$ [green $(-)$ to red $(+)$ ], and $b^{*}$ [blue (-) to yellow (+)].

\section{Results and Discussion}

3.1. Adjustment of the Model. In order to evaluate the effect of roasting time and temperature on the physicochemical parameters and to elucidate the most suitable conditions to optimize the process of roasted cocoa beans, a surface response methodology (SRM) according to a central composite design was applied. This technique, based on a statistical experimental design, has been applied in various fields in recent years with excellent results $[8,14-17]$. The effects of roasting time and temperature in a rotating drum system by batches on moisture, water activity $\left(a_{w}\right)$, total acidity, $\mathrm{pH}$, color parameters $\left(L^{*}, a^{*}, b^{*}\right)$, total phenolic content (TPC), and scavenging capacity of the DPPH radical after roasting are shown in Table 2. The analysis of variance (ANOVA) on the aforementioned response variables as a function of their linear, quadratic, and interaction terms in addition to the goodness of fit test is shown in Table 3. In SRM it is always necessary to verify the model adjustment to ensure a genuine approach and to verify that the assumptions of regression by minimum squares are met. Aftershocks on the central points are necessary for a formal goodness of fit test of the regression model [18]. Table 4 shows the regression coefficients associated with second-order polynomial model for the response variables.

The results showed that the models for all responses were appropriated in function of the coefficient of determination $R^{2}$, which was higher than $70 \%[18,19]$, indicating that the model regression satisfactorily explains the roasting process with the exception of TPC and DPPH scavenging capacity, both in aqueous medium. The models and their respective surface responses were adjusted by excluding the nonsignificant statistical parameters at $p>0.05$.

The study showed that there was no significant lack of fit $(p<0.05)$ in the responses of moisture, $a_{w}, \mathrm{pH}$, $L^{*}, a^{*}$, and TPC in an ethanolic extract and scavenging of DPPH radical capacity in aqueous and ethanolic extracts (Table 3). According to Noor-Soffalina et al. [8], a model with significant lack of fit can be attributed to the fact that not all independent variables were considered appropriately within the function. However, when a large amount of data is included in a study, a scarce adjustment from model can be used. In response variables that showed adjustment scarcity, it can be seen that the value of $R^{2}$ was greater than $70 \%$ (Table 3).

3.2. Changes in Moisture Content and $a_{w}$ as an Effect of Roasting Time and Temperature. Moisture content is the parameter most evaluated during roasting seeds and grains and on which the different dependent variables are conditioned because there is a limit to biological safety and quality. Moisture cannot be reduced below a humidity limit, because the grain obtained will be burned and all the quality attributes are lost. Changes in moisture content are used as a quality tool to determine the combined features of flavor and aroma after roasting [20]; therefore, the moisture content is a variable used as a control and optimization variable because it defines the end point of roasting [4]. The particular case of cocoa beans roasting process aimed to reach a final moisture content

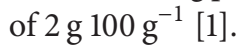

The moisture content changed from 0.003 to $0.028 \mathrm{~g}$ water $^{-1} \mathrm{dm}^{-1}$, during the design treatments (Table 2). Water activity showed values in the range 0.31 to 0.54 , which permits the inhibition of bacterial growth. 


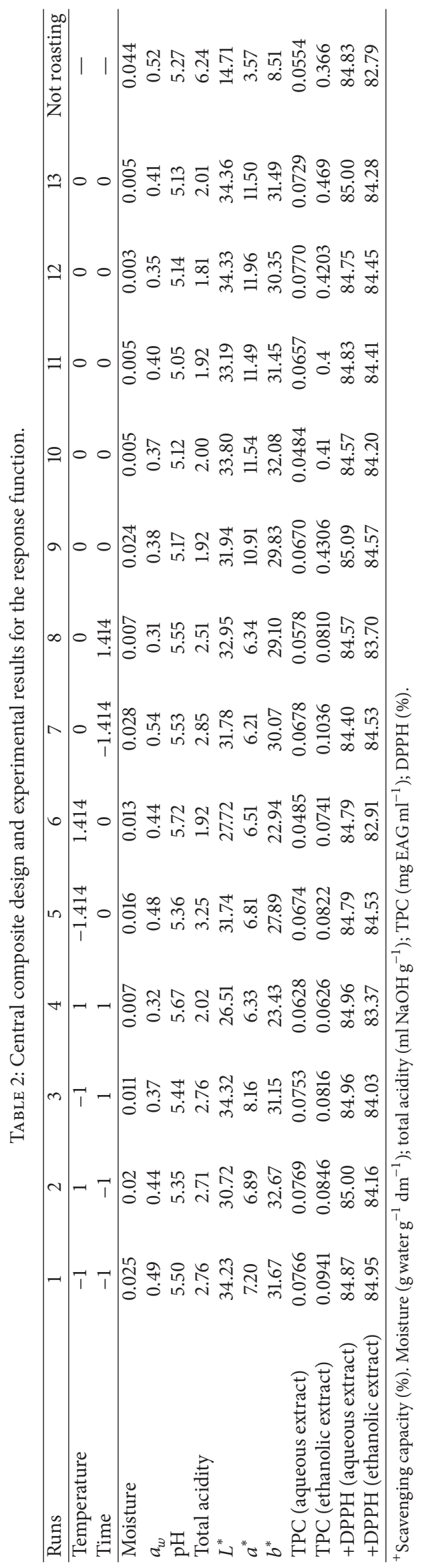




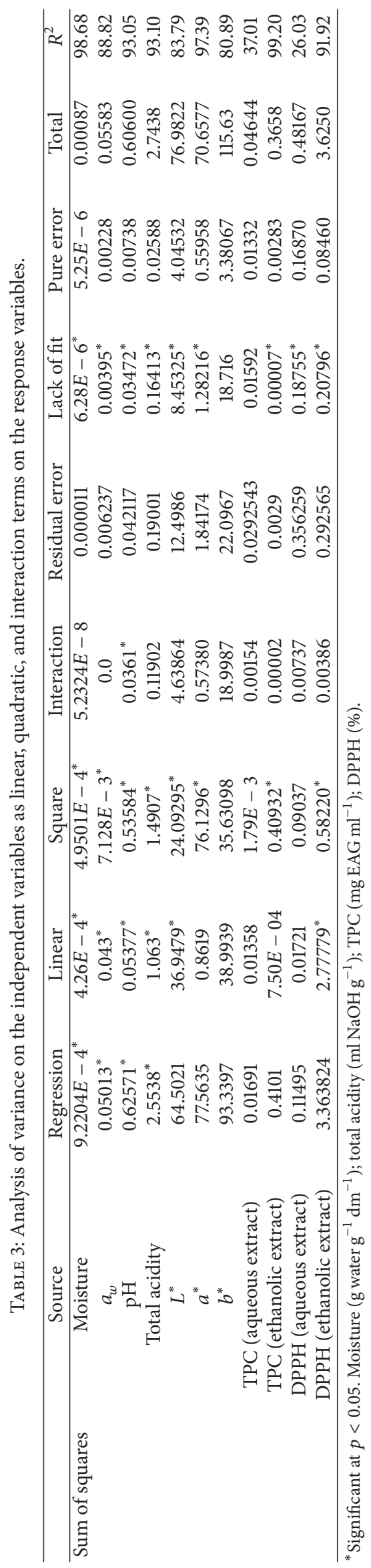


TABLE 4: Regression coefficients of the second-order polynomial for the response variables.

\begin{tabular}{|c|c|c|c|c|c|c|}
\hline Coefficients & $\beta_{0}$ & $\beta_{1}$ & $\beta_{2}$ & $\beta_{12}$ & $\beta_{11}$ & $\beta_{22}$ \\
\hline Moisture & 0.004072 & $-0.001666^{*}$ & $-0.007113^{*}$ & 0.0001143 & $0.0051095^{*}$ & $0.00671198^{*}$ \\
\hline$a_{w}$ & 0.382 & -0.0195711 & $-0.0706587^{*}$ & 0.0 & 0.029625 & 0.0121249 \\
\hline $\mathrm{pH}$ & 5.1225 & $0.0736396^{*}$ & 0.0360356 & $0.095^{*}$ & $0.1962^{*}$ & $0.19625^{*}$ \\
\hline Total acidity & 1.932 & $-0.33388^{*}$ & $-0.14637^{*}$ & -0.1725 & $0.30904^{*}$ & $0.35655^{*}$ \\
\hline$L^{*}$ & 33.523 & $-2.12684^{*}$ & -0.308302 & $-1.07688^{*}$ & $-1.79807^{*}$ & -0.479936 \\
\hline$a^{*}$ & 11.48 & -0.319726 & 0.0743069 & -0.37875 & $-2.24032^{*}$ & $-2.43407^{*}$ \\
\hline$b^{*}$ & 31.0405 & $-1.71448^{*}$ & -1.39098 & $-2.17938^{*}$ & $-2.25682^{*}$ & -0.169932 \\
\hline TPC (aqueous extract) & 0.066258 & -0.00490562 & -0.00354967 & -0.0031825 & -0.000963359 & 0.00129165 \\
\hline TPC (ethanolic extract) & 0.425 & -0.009966 & -0.01665153 & -0.00475 & $-0.350081^{*}$ & -0.335931 \\
\hline +DPPH (aqueous extract) & 84.8519 & 0.0214751 & 0.0411203 & -0.04295 & 0.0461133 & -0.104237 \\
\hline +DPPH (ethanolic extract) & 84.3863 & $-0.467218^{*}$ & $-0.359071^{*}$ & 0.031075 & $-0.277771^{*}$ & -0.0808446 \\
\hline
\end{tabular}

${ }^{*}$ Significant at $p<0.05 ;^{+}$scavenging capacity. Moisture $\left(\mathrm{g}\right.$ water $\left.^{-1} \mathrm{dm}^{-1}\right)$; total acidity $\left(\mathrm{ml} \mathrm{NaOH} \mathrm{g}^{-1}\right)$; TPC $\left(\mathrm{mg} \mathrm{EAG} \mathrm{ml}^{-1}\right)$; DPPH (\%).

With respect to the initial value of water activity (0.52), all treatments obtained during roasting process showed lower values (except that of treatment number seven). The result that showed greater water activity coincides with higher moisture content. The water activity plays an important role in the rate of browning reaction, which is maximum for intermediate values in a range of 0.6 to 0.7 [2]. The initial values of the samples before the roasting process in the present investigation were below the aforementioned values and depend on the postharvest treatment. Therefore, the fermentation and drying process should consider this parameter within the variables to be optimized prior to the roasting process.

The ANOVA results showed that roasting time and temperature were significant factors $(p<0.05)$ and the goodness of fit test indicated that the selected model was suitable to describe the observed data for the moisture content and $a_{w}$. Similarly, moisture and $a_{w}$ exhibited linear negative and nonlinear positive effect in the linear and quadratic terms $\left(\beta_{1}\right.$, $\beta_{11}, \beta_{2}, \beta_{22}$ ) significant at $p<0.05$ (Figures 1 (a) and $1(\mathrm{~b})$ ). The surface response moisture shows the curvature generated and the contours delineate the convergence towards a (minimum) stationary point, while the surface to $a_{w}$ exhibited a behavior of an ascending peak indicating that the stationary point is outside the experimental region.

3.3. Changes in Total Acidity and $p H$ as an Effect of the Roasting Time and Temperature. During the traditional fermentation of cocoa, a volatile fraction of organic acids is formed, mainly acetic acid. This acid is partially removed during drying and roasting [21-23]. In roasting, the volatile compounds, total acidity, $\mathrm{pH}$, and fat content depend on the conditions of temperature and process time [9, 2325]. The effect of $\mathrm{pH}$ has been evaluated in model studies finding a close relationship with the formation of volatile compounds; for example, low $\mathrm{pH}(\leq 5)$ favors the formation of pyrazines and higher $\mathrm{pH}$ favors the methylpyrazines $[2,26]$. In roasting studies maintaining $\mathrm{pH}$ to 5.0 , the formation of many nitrogen compounds as pyrroles and pyridines [2] is promoted. The pyrazines group play a very important part because they represent about $40 \%$ of the fermented cocoa aroma [27]. In the present study, the range of $\mathrm{pH}$ values was 5.05-5.72, where each treatment was different with respect to the initial condition of roasting, for which the $\mathrm{pH}$ value was 5.27, favoring the formation of volatile compounds such as methylpyrazines, pyrroles, and pyridines.

The results of total acidity found were located in the range of $1.81-3.25 \mathrm{ml} \mathrm{NaOH}(0.1 \mathrm{~N}) \mathrm{g}^{-1}$, indicating a significant change from the initial value of $6.24 \mathrm{ml} \mathrm{NaOH}(0.1 \mathrm{~N}) \mathrm{g}^{-1}$ (Table 2). The decrease was attributed to the removal of volatile organic acids, primarily acetic acid. As a result of this decrease, significant changes were recorded in the $\mathrm{pH}$ with respect to the initial value. In addition, in design treatments, the results showed an inverse relationship between acidity and $\mathrm{pH}$; the lower the total acidity values, the higher the $\mathrm{pH}$ values (Table 2).

The ANOVA results showed a significant effect $(p<0.05)$ of the study factors on the total acidity and $\mathrm{pH}$. The goodness of fit test indicated that the model selected was suitable for the $\mathrm{pH}$ data observed. The temperature and time showed a positive linear and nonlinear effect on the $\mathrm{pH}$, indicating that an increase in the conditions of these factors caused an increase in the $\mathrm{pH}$, being more marked in the nonlinear effect, which implies a convex behavior. In the case of total acidity, the temperature effect was linearly negative and for some time nonlinearly positive (Table 3 ). For both response variables significant linear terms were presented, both interaction and quadratic. The $\mathrm{pH}$ changes and total acidity during roasting in rotary drum can be seen on the surfaces in Figures 1(c)$1(d)$, where the presence of a (minimum) stationary point is observed in each case. The $\mathrm{pH}$ showed a more pronounced curvilinear effect with respect to total acidity.

\subsection{Changes in Color Parameters as an Effect of Roasting} Time and Temperature. Color is an important parameter that together with moisture is used as a variable to determine the control of a process. Color is widely used in roasted beans as an indicator of the progress of browning and caramelization reactions, temperature being the main factor that causes these changes [24, 28, 29]. 


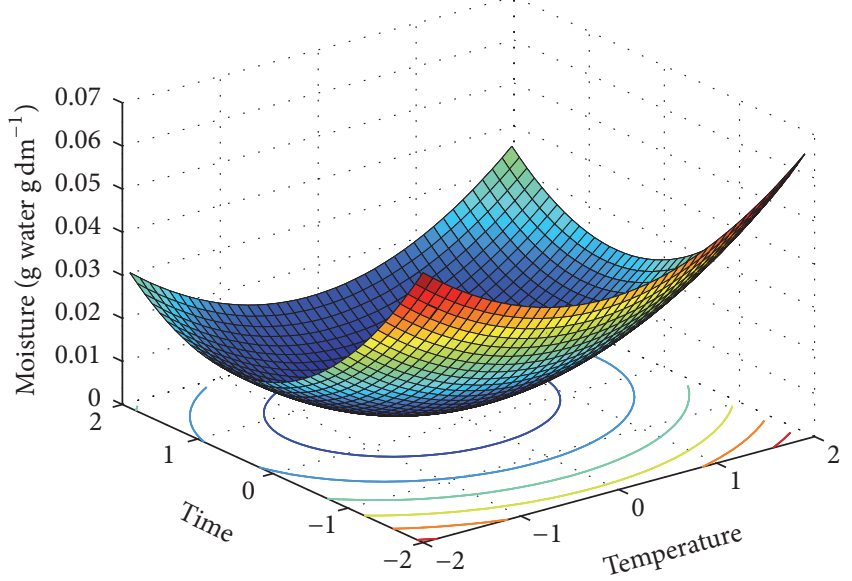

(a)

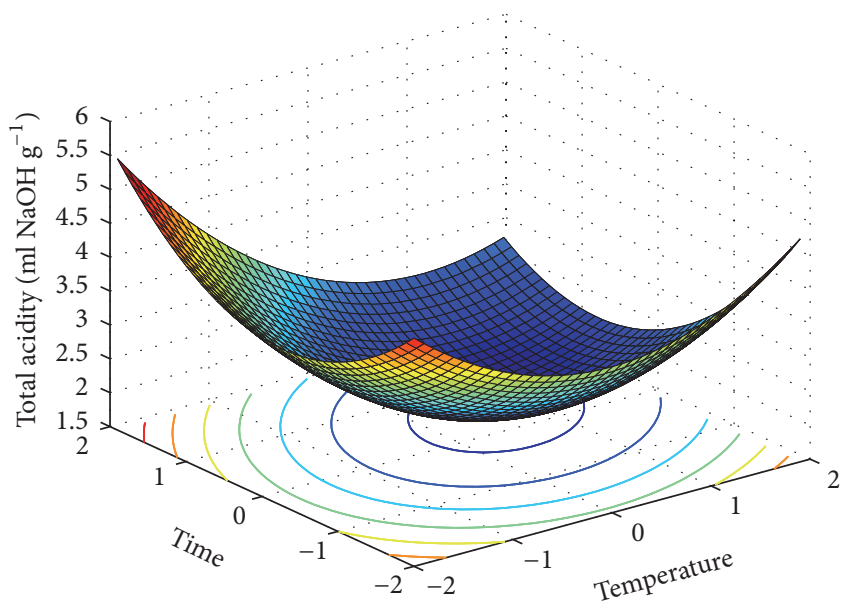

(c)

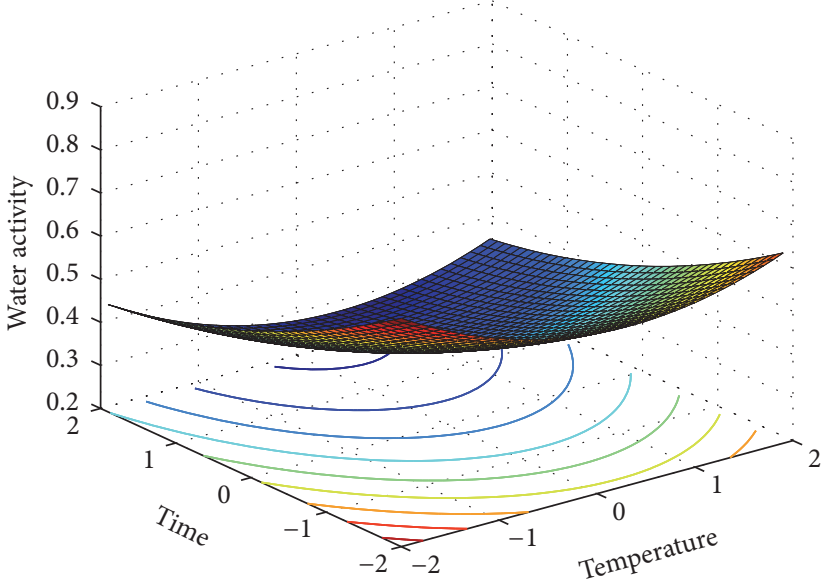

(b)

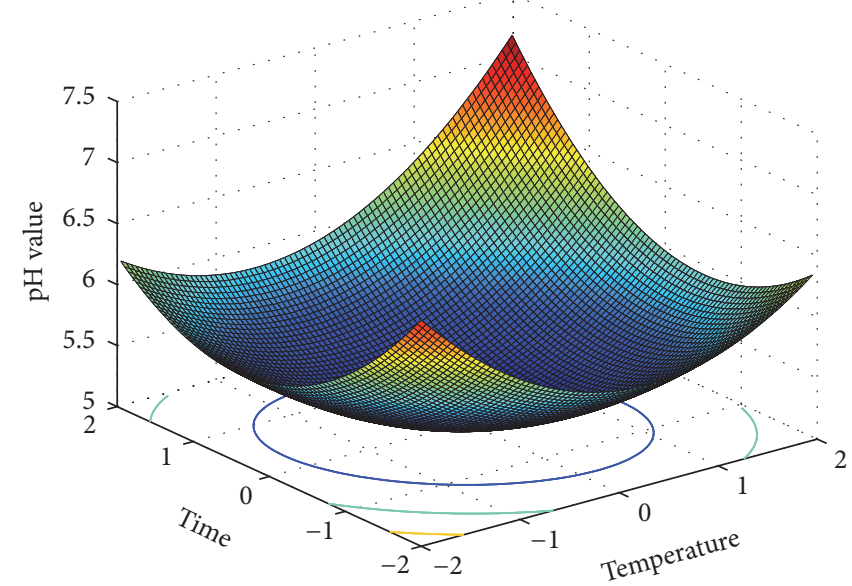

(d)

FIgURE 1: The surface plots of moisture (a), water activity (b), total acidity (c), and $\mathrm{pH}(\mathrm{d})$ as affected by roasting time and temperature.

Color parameters $L^{*}, a^{*}$, and $b^{*}$ observed in cocoa beans were widely modified with respect to the initial values (Table 2). Although there are reported different methods of roasting cocoa, generally, values for these parameters should reach similar values under optimum conditions. For the $L^{*}$ parameter, values were obtained in the range of 26.51-34.36, being lower than the average value of 39.25 , reported by Zzaman and Yang [20] for a temperature range of $124-140^{\circ} \mathrm{C}$ and $900-1100 \mathrm{~kg} \mathrm{~h}^{-1}$ power, and also less than that reported by Żyżelewicz et al. [28] whose $L^{*}$ value was $32.43-37.20$, to a temperature of $135-150^{\circ} \mathrm{C}$, using a convective roasting system. In the above cited references, the $L^{*}$ value dissipated by increasing the brightness.

Zzaman et al. [30] reported the use of superheated steam to roast cocoa in a range of $150-250^{\circ} \mathrm{C}$, finding that the $L^{*}$ value increases with this method with respect to the initial value. These authors argue that this change could be a function of the protein denaturation, along with the amount of fat around the matrix protein, combined with low moisture levels. De Brito et al. [11] achieved constant protein levels and observed that the free amino acids were reduced as a result of Maillard reactions, which depend on roasting time and temperature.

As for the green-red given by $a^{*}$, it was found between 6.21 and 11.96, and for the blue-yellow given by $b^{*}$, it was found between 22.94 and 32.67. The values by $a^{*}$ with respect to research by Żyżelewicz et al. [28] were similar to and coincide with the central points obtained by Lee et al. [23]. However, Zzaman et al. [30] found a sudden increase after $30 \mathrm{~min}$, between 200 and $250^{\circ} \mathrm{C}$, and at the end of roasting, the reported values are above those of the present work and those listed above. Changes in this parameter are associated with the formation of brown pigments due to condensation and polymerization reactions $[24,28,30]$.

With respect to parameter $b^{*}$, marked differences were recorded, while Żyżelewicz et al. [28] reported values between 2.48 and 6.68, Lee et al. [23] obtained values between 10.38 and 12.47, and Zzaman et al. [30] obtained values between 10 and 20 at the end of the roasting process. The changes observed for $b^{*}$ are similarly associated with that for $a^{*}$ depending on brown pigment formation. In all cases, $a^{*}$ and $b^{*}$ parameters increased with respect to the initial value. The 


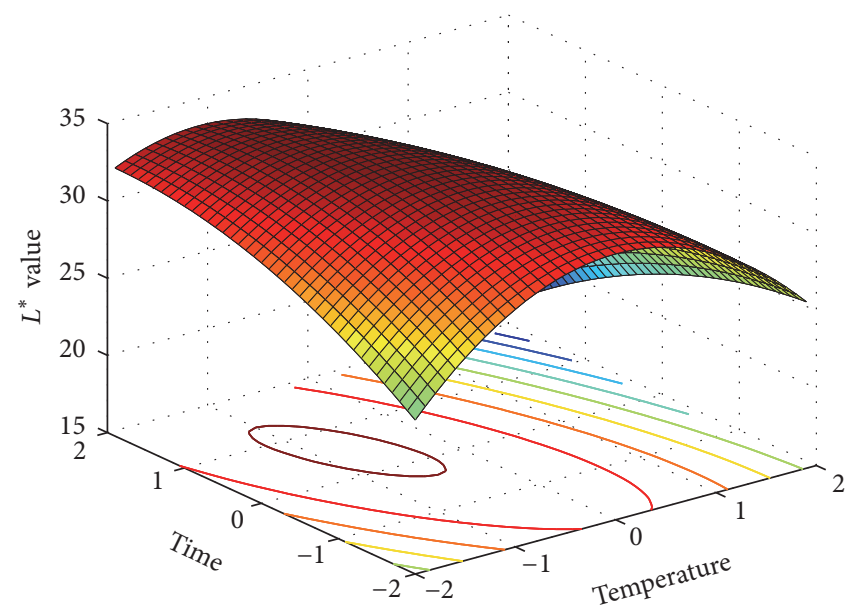

(a)

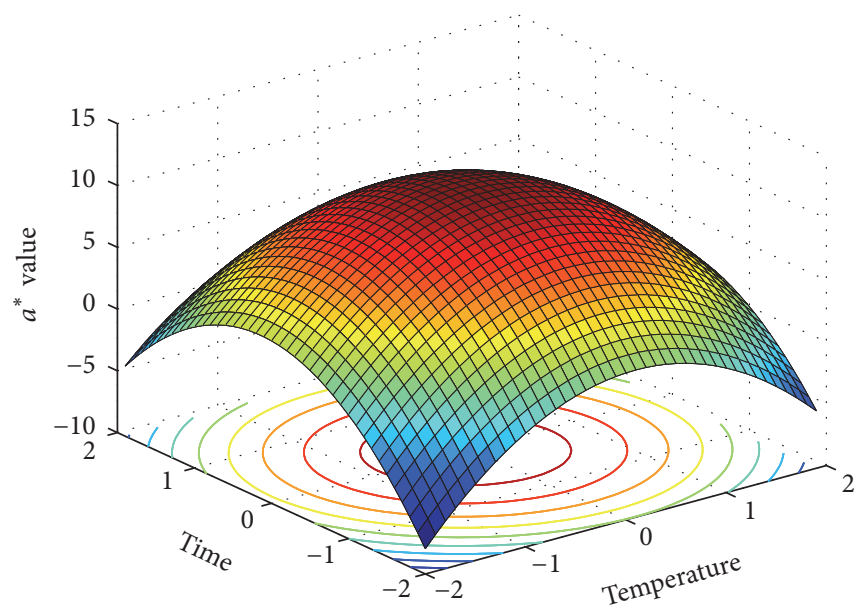

(b)

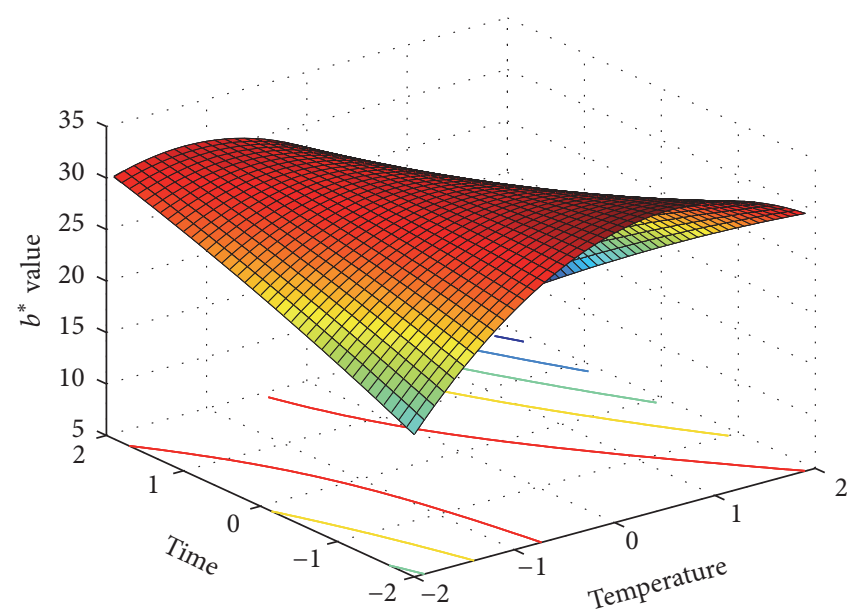

(c)

FIgURE 2: The surface plots of color instrumental. $L^{*}$ value (a), $a^{*}$ value (b), and $b^{*}$ value (c) as affected by roasting time and temperature.

different methods of cocoa beans roasting process increase or decrease the color parameters $L^{*}, a^{*}$, and $b^{*}$, with particular differences at $b^{*}$, which are function of cocoa beans pigments concentration, and they also depend on the degradation during fermentation and drying process.

The ANOVA results showed a significant effect $(p<0.05)$ of the study factors on the color parameters $L^{*}, a^{*}$, and $b^{*}$. The goodness of fit test indicated that the model selected for the case of $L^{*}$ and $a^{*}$ was suitable for the observed data. The coefficient of determination $R^{2}$ was higher than $70 \%$ for all color parameters. Temperature and time showed a negative nonlinear effect on $L^{*}, a^{*}$, and $b^{*}$. A negative linear effect was particular on $L^{*}$ and $b^{*}$ as function of roasting temperature. The surface plots of color parameters are shown in Figures $2(\mathrm{a})-2(\mathrm{c})$.

3.5. Changes in Total Phenolic Content (TPC) as an Effect of Roasting Time and Temperature. Phenolic compounds content is modified during roasting process and they are responsible for a fraction of bitterness and astringency of cocoa beans $[9,23]$, so that different conditions of roasting time and temperature will change their contents and therefore the sensorial attributes. The decrease of total phenolic content (TPC) induces primary flavors, which through chemical reactions of complexation and polymerization generate the characteristic chocolate flavor [23].

The results on TPC in aqueous extracts of roasted cocoa beans were $0.0484-0.0770 \mathrm{mgEAG} \mathrm{ml}^{-1}$ and those of ethanolic extracts were 0.0626-0.469 $\mathrm{mg} \mathrm{EAG} \mathrm{ml}^{-1}$ (Table 2). The principal differences were attributed as a function of the solubility in solvent. The ethanolic extract showed higher affinity to extraction for phenolic compounds in cocoa beans; this result confirms that reported by Othman et al. [13]. The values of TPC of the treatments were similar to those reported by Lee et al. [23]; they evaluated temperature conditions of $124-140^{\circ} \mathrm{C}$ and load of $900-1100 \mathrm{~kg} \mathrm{~h}^{-1}$. These changes of TPC in magnitude are not significant but have a fundamental role in sensorial attributes.

Roasting time and temperature were found to be nonsignificant factors $(p>0.05)$ for TPC in aqueous extracts (Table 3). On the other hand the results revealed that roasting time and temperature were significant factors by TPC in 


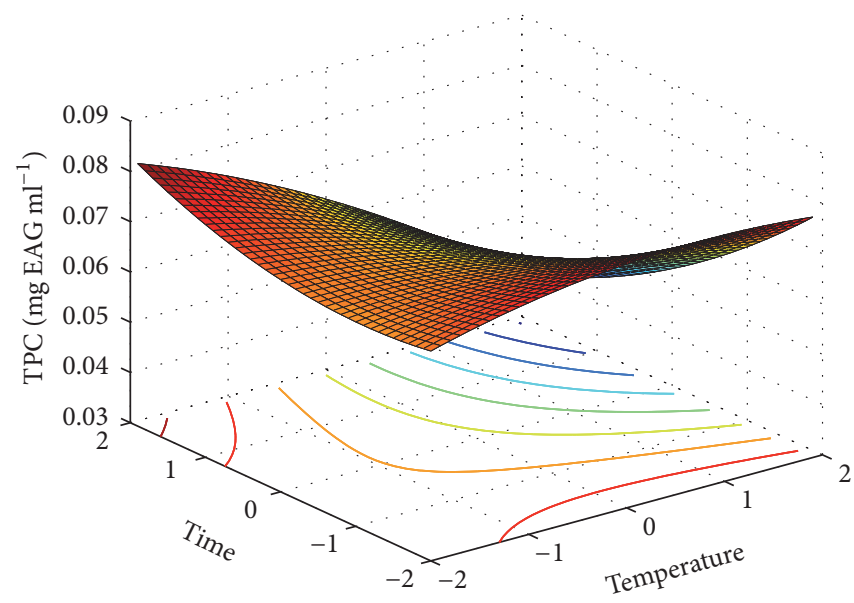

(a)

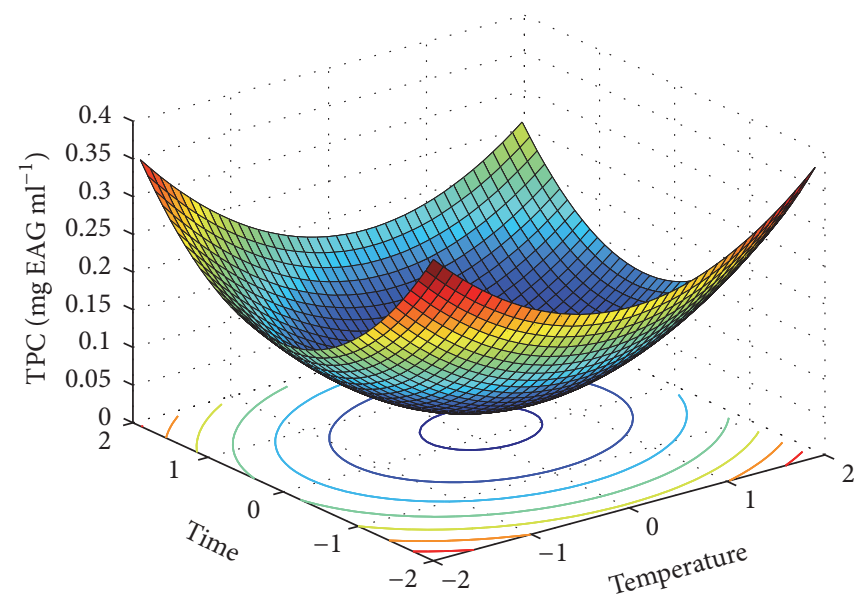

(b)

FIGURE 3: The surface plots of total phenolic content $\left(\mathrm{mg} \mathrm{EAG} \mathrm{ml}^{-1}\right)$ in aqueous extract (a) and ethanolic extract (b) as affected by roasting time and temperature.

ethanolic extract $(p<0.05)$. The statistical analysis data revealed that quadratic terms were significant. The total coefficient of determination $\left(R^{2}\right)$ was $99.20 \%$ indicating a reasonable fit of the model to the experimental data. The linear, interaction, and quadratic terms were negative (Table 3 ) indicating that an increase in these factors caused a decrease in TPC in ethanolic extracts.

Results similar to our research are confirmed by Jinap et al. [9]; they evaluated roasting time and temperature at cocoa beans nibs in conventional tray oven. This authors applying response surface methodology found that unit areas of phenols decreased with temperatures between 160 and $170^{\circ} \mathrm{C}$ and time of 45-65 min. Zzaman et al. [20] reported similar results in roasted system with superheated steam in a range of $150-250^{\circ} \mathrm{C}$. Lee et al. [23] have shown that temperatures higher than $130^{\circ} \mathrm{C}$ cause a gradual decrease on TPC as a function between polyphenols and intermediate products of brown reactions. The decrease of TPC is associated with thermal and oxidative degradation of these compounds. The plot of response surface of TPC is shown in Figure 3.

3.6. Scavenging Activity on 1,1-Diphenyl-2-picrylhydrazyl (DPPH) Radical as Effect of the Roasting Time and Temperature. The test using the reduction of the DPPH radical in the presence of phenolic compounds is very popular in food research. This test is based on the decrease of the absorbance of the radical solution according to the reaction DPPH with phenolic antioxidants $[13,31,32]$. DPPH is one of the compounds that possesses a proton free radical and shows a maximum absorption at $517 \mathrm{~nm}$ [13].

The results as a function of roasting time and temperature are shown in Table 2. The treatments did not show remarkable changes about initial value of extracts, but the ANOVA showed significative differences $(p<0.05)$ between treatments. The range of scavenging of DPPH radical capacity was $84.40-85.09 \%$ and $82.91-84.95 \%$ in water and ethanolic extracts, respectively. These results were different compared to Zzamman and Yang [20]; they reported a decrease of the scavenging of DPPH radical in methanolic extracts before and after roasting process; nevertheless Othman et al. [13], Arlorio et al. [33], and Summa et al. [34] mentioned that DPPH radical capacity is affected by other compounds such as methylxanthines, flavonoids, and pigments, in addition to the variety, postharvest, extraction methods, solvents, and extract concentration. Summa et al. [34] reported that the scavenging of DPPH radical increases significantly after roasting process in fractions of $10-5 \mathrm{kDa}$, corresponding to the region of molecular weight of melanoidins. Othman et al. [13] found no correlation between scavenging activity and the TPC and they indicated that a high scavenging ability on DPPH radical could not be due to phenolic compounds in the cocoa beans extracts. Our study similarly showed no correlation between scavenging abilities on DPPH radical and total phenolics compounds. The capacity of scavenging of the extracts of cocoa beans during roasting process could also be due to other compounds besides phenolics which are soluble in water and ethanol.

The results of ANOVA showed that roasting time and temperature affected the DPPH radical capacity in ethanolic extract, but not in aqueous extract. The terms showed that negative linear and quadratic effect both were significant $(p<0.05)$ indicating that an increase of the roasting time and temperature conditions decreased the DPPH radical capacity in ethanolic extract. Figures 4(a)-4(b) show the response surface plot of DPPH radical capacity in ethanolic and aqueous extract compared to roasting process. The plot of ethanolic extract showed a geometry of elliptical contours, while that of aqueous extract was of a saddle point.

\section{Conclusions}

The temperature and time conditions applied during cocoa beans roasting process in a rotary drum system presented a significant nonlinear response for different physicochemical 


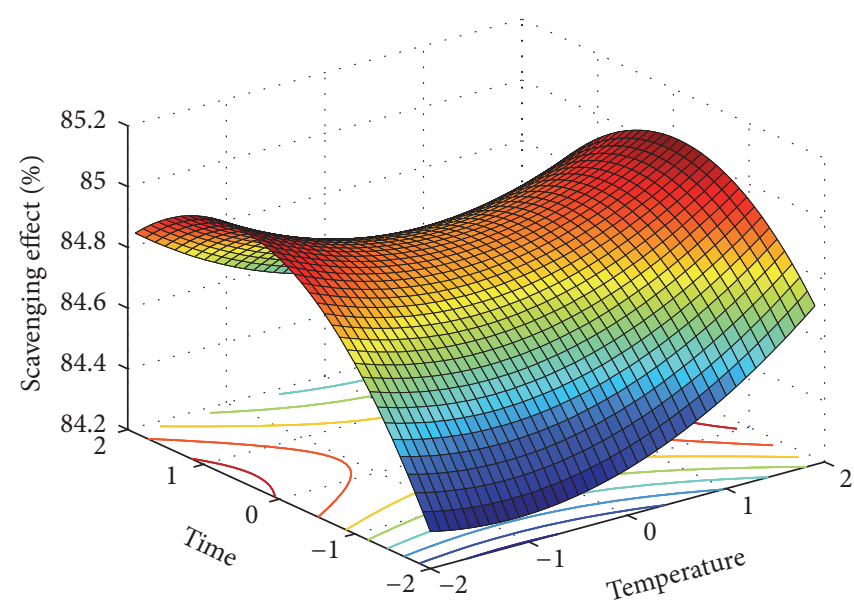

(a)

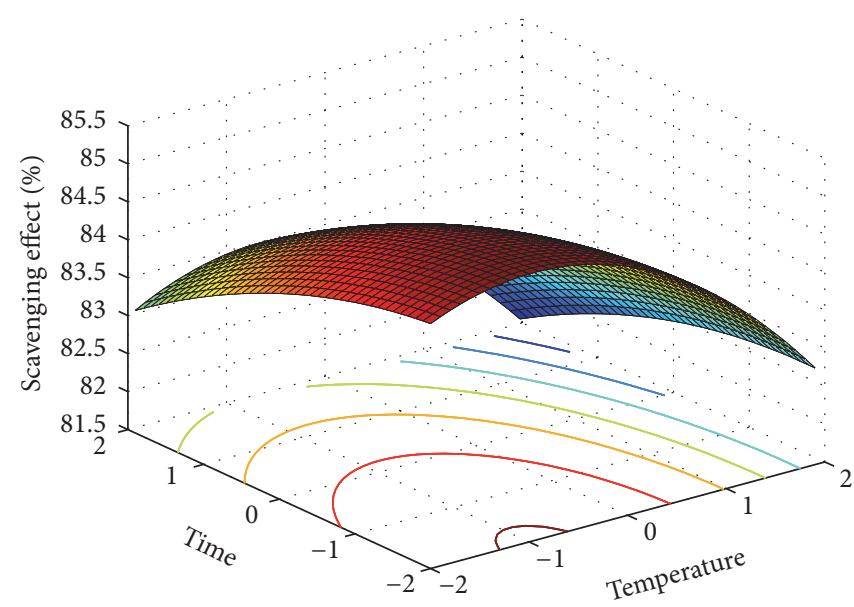

(b)

FIGURE 4: The surface plots of scavenging capacity of DPPH radical in aqueous extract (a) and ethanolic extract (b) as affected by roasting time and temperature.

variables, which can be represented by a polynomial of second-order response. The results showed a decrease and in other cases an increase of the variables, which implies that the flavor and aroma characteristics will have also to be modified, and therefore it will be necessary to establish roasting optimum conditions which should consider the traceability from the harvest. The model equation developed for physicochemical responses can be used for prediction during roasting process.

\section{Conflicts of Interest}

The authors declare that there are no conflicts of interest regarding the publication of this paper.

\section{References}

[1] G. Sacchetti, F. Ioannone, M. De Gregorio, C. Di Mattia, M. Serafini, and D. Mastrocola, "Non enzymatic browning during cocoa roasting as affected by processing time and temperature," Journal of Food Engineering, vol. 169, article 8295, pp. 44-52, 2016.

[2] E. Cros, "Torréfaction. En Cacao et chocolat. production, utilisation, caractéristiques," in Collection sciences techniques agroalimentaires, (Technique \& Documentation Lavoisier), Paris Cedex 08, France, 1998.

[3] R. Saltini, R. Akkerman, and S. Frosch, "Optimizing chocolate production through traceability: a review of the influence of farming practices on cocoa bean quality," Food Control, vol. 29, no. 1, pp. 167-187, 2013.

[4] J. A. Hernández, B. Heyd, C. Irles, B. Valdovinos, and G. Trystram, "Analysis of the heat and mass transfer during coffee batch roasting," Journal of Food Engineering, vol. 78, no. 4, pp. 1141-1148, 2007.

[5] H. Schwartzberg, "Modeling Bean Heating during Batch Roasting of Coffee Beans," in Engineering and Food for the 21st Century, J. Welti-Chanes, G. Barbosa-Canovas, and J. M. Aguilera, Eds., vol. 5 of Food Preservation Technology, CRC Press, 2002.
[6] M. J. Serrano-Maldonado, I. Guerrero-Legarreta, C. De la Paz Pérez-Olvera, and J. Soriano-Santos, "ntioxidant activity and citotoxic effect of Cladocolealoniceroides (van Tieghem) Kuijt (loranthaceae)," Revista Mexicana de Ingeniería Química, vol. 10, pp. 161-170, 2011.

[7] E. García-Márquez, A. Román-Guerrero, C. Pérez-Alonso, F. Cruz-Sosa, R. Jiménez-Alvarado, and E. J. Vernon-Carter, "Effect of solvent-temperature extraction conditions on the initial antioxidant activity and total phenolic content of muitle extracts and their decay upon storage at different $\mathrm{pH}$," Revista Mexicana de Ingeniería Química, vol. 11, no. 1, pp. 1-10, 2012.

[8] S. S. Noor-Soffalina, S. Jinap, S. Nazamid, and S. A. H. Nazimah, "Effect of polyphenol and $\mathrm{pH}$ on cocoa Maillard-related flavour precursors in a lipidic model system," International Journal of Food Science and Technology, vol. 44, no. 1, pp. 168-180, 2009.

[9] S. Jinap, W. I. Wan Rosli, A. R. Russly, and L. M. Nordin, "Effect of roasting time and temperature on volatile component profiles during nib roasting of cocoa beans (Theobroma cacao)," Journal of the Science of Food and Agriculture, vol. 77, no. 4, pp. 441-448, 1998.

[10] F. Ioannone, C. D. Di Mattia, M. De Gregorio, M. Sergi, M. Serafini, and G. Sacchetti, "Flavanols, proanthocyanidins and antioxidant activity changes during cocoa (Theobroma cacao L.) roasting as affected by temperature and time of processing," Food Chemistry, vol. 174, pp. 256-262, 2015.

[11] E. S. De Brito, N. H. P. García, M. I. Gallão, A. L. Cortelazzo, P. S. Fevereiro, and M. R. Braga, "Structural and chemical changes in cocoa (Theobroma cacao L) during fermentation, drying and roasting," Journal of the Science of Food and Agriculture, vol. 81, no. 2, pp. 281-288, 2001.

[12] J. Pontillon and E. Cros, "Méthodes analytiques pour le cacao et produits dérivés. En Cacao et chocolat. production, utilisation, caractéristiques," in Collection sciences \& techniques agroalimentaire, (Technique \& Documentation Lavoisier), Paris Cedex 08, France, 1998.

[13] A. Othman, A. Ismail, N. Abdul Ghani, and I. Adenan, "Antioxidant capacity and phenolic content of cocoa beans," Food Chemistry, vol. 100, no. 4, pp. 1523-1530, 2007. 
[14] D. M. H. Farah, A. H. Zaibunnisa, and Misnawi, "Optimization of cocoa beans roasting process using response surface methodology based on concentration of pyrazine and acrylamide," International Food Research Journal, vol. 19, no. 4, pp. 1355-1359, 2012.

[15] V. A. Sakkas, M. A. Islam, C. Stalikas, and T. A. Albanis, "Photocatalytic degradation using design of experiments: a review and example of the Congo red degradation," Journal of Hazardous Materials, vol. 175, no. 1-3, pp. 33-44, 2010.

[16] C. R. T. Tarley, G. Silveira, W. N. L. dos Santos et al., "Chemometric tools in electroanalytical chemistry: methods for optimization based on factorial design and response surface methodology," Microchemical Journal, vol. 92, no. 1, pp. 58-67, 2009.

[17] M. A. Bezerra, R. E. Santelli, E. P. Oliveira, L. S. Villar, and L. A. Escaleira, "Response surface methodology (RSM) as a tool for optimization in analytical chemistry," Talanta, vol. 76, no. 5, pp. 965-977, 2008.

[18] D. C. Montgomery, Design and Analysis of Experiments, John Wiley \& Sons, 8th edition, 2012.

[19] H. Gutiérrez-Pulido and R. N. de la Vara-Salazar, Análisis $Y$ Diseño De Experimentos, Mc Graw Hill Interamericana, México, 2008.

[20] W. Zzaman and T. A. Yang, "Moisture, color and texture changes in cocoa beans during superheated steam roasting," Journal of Food Processing and Preservation, vol. 38, no. 3, pp. 1364-1370, 2014.

[21] D. Páramo, P. García-Alamilla, M. A. Salgado-Cervantes, V. J. Robles-Olvera, G. C. Rodríguez-Jimenes, and M. A. GarcíaAlvarado, "Mass transfer of water and volatile fatty acids in cocoa beans during drying," Journal of Food Engineering, vol. 99, no. 3, pp. 276-283, 2010.

[22] P. García-Alamilla, M. A. Salgado-Cervantes, M. Barel, G. Berthomieu, G. C. Rodríguez-Jimenes, and M. A. GarcíaAlvarado, "Moisture, acidity and temperature evolution during cacao drying," Journal of Food Engineering, vol. 79, no. 4, pp. 1159-1165, 2007.

[23] S. Lee, S. Yoo, M. Lee, I. Kwon, and Y. Pyun, "Optimization of nibs roasting in cocoa bean processing with lotte-better taste and color process," Food Science and Biotechnology, vol. 10, pp. 286-293, 2001.

[24] W. Krysiak, "Influence of roasting conditions on coloration of roasted cocoa beans," Journal of Food Engineering, vol. 77, no. 3, pp. 449-453, 2006.

[25] N. Ramli, O. Hassan, M. Said, W. Samsudin, and N. A. Idris, "Influence of roasting conditions on volatile flavor of roasted Malaysian cocoa beans," Journal of Food Processing and Preservation, vol. 30, no. 3, pp. 280-298, 2006.

[26] A. Apriyantono and J. M. Ames, "Xylose-lysine model systems: the effect of $\mathrm{pH}$ on the volatile reaction products," Journal of the Science of Food and Agriculture, vol. 61, no. 4, pp. 477-484, 1993.

[27] P. Hashim, J. Selamat, S. K. S. Muhammad, and A. Ali, "Changes in free amino acid, peptide- $\mathrm{N}$, sugar and pyrazine concentration during cocoa fermentation," Journal of the Science of Food and Agriculture, vol. 78, no. 4, pp. 535-542, 1998.

[28] D. Żyżelewicz, W. Krysiak, E. Nebesny, and G. Budryn, "Application of various methods for determination of the color of cocoa beans roasted under variable process parameters," European Food Research and Technology, vol. 238, no. 4, pp. 549563,2014

[29] A. Shakerardekani, R. Karim, H. Mohd Ghazali, and N. L. Chin, "Effect of roasting conditions on hardness, moisture content and colour of pistachio kernels," International Food Research Journal, vol. 18, no. 2, pp. 723-729, 2011.

[30] W. Zzaman, R. Bhat, and T. A. Yang, "Effect of superheated steam roasting on the phenolic antioxidant properties of cocoa beans," Journal of Food Processing and Preservation, vol. 38, no. 4, pp. 1932-1938, 2014.

[31] W. Brand-Williams, M. E. Cuvelier, and C. Berset, "Use of a free radical method to evaluate antioxidant activity," LWT-Food Science and Technology, vol. 28, no. 1, pp. 25-30, 1995.

[32] A. Reyes-Munguía, E. Azúara-Nieto, C. I. Beristain, F. CruzSosa, and E. J. Vernon-Carter, "Purple maguey (Rhoeo discolor) antioxidant properties," Ciencia y Tecnologia Alimentaria, vol. 7, no. 3, pp. 209-216, 2009.

[33] M. Arlorio, M. Locatelli, F. Travaglia et al., "Roasting on the contents of clovamide ( $N$-caffeoyl-L-DOPA) and the antioxidant activity of cocoa beans (Theobroma cacaoL.)," Food Chemistry, vol. 106, no. 3, pp. 967-975, 2008.

[34] C. Summa, F. C. Raposo, J. McCourt et al., "Effect of roasting on the radical scavenging activity of cocoa beans," European Food Research and Technology, vol. 222, no. 3-4, pp. 368-375, 2006. 

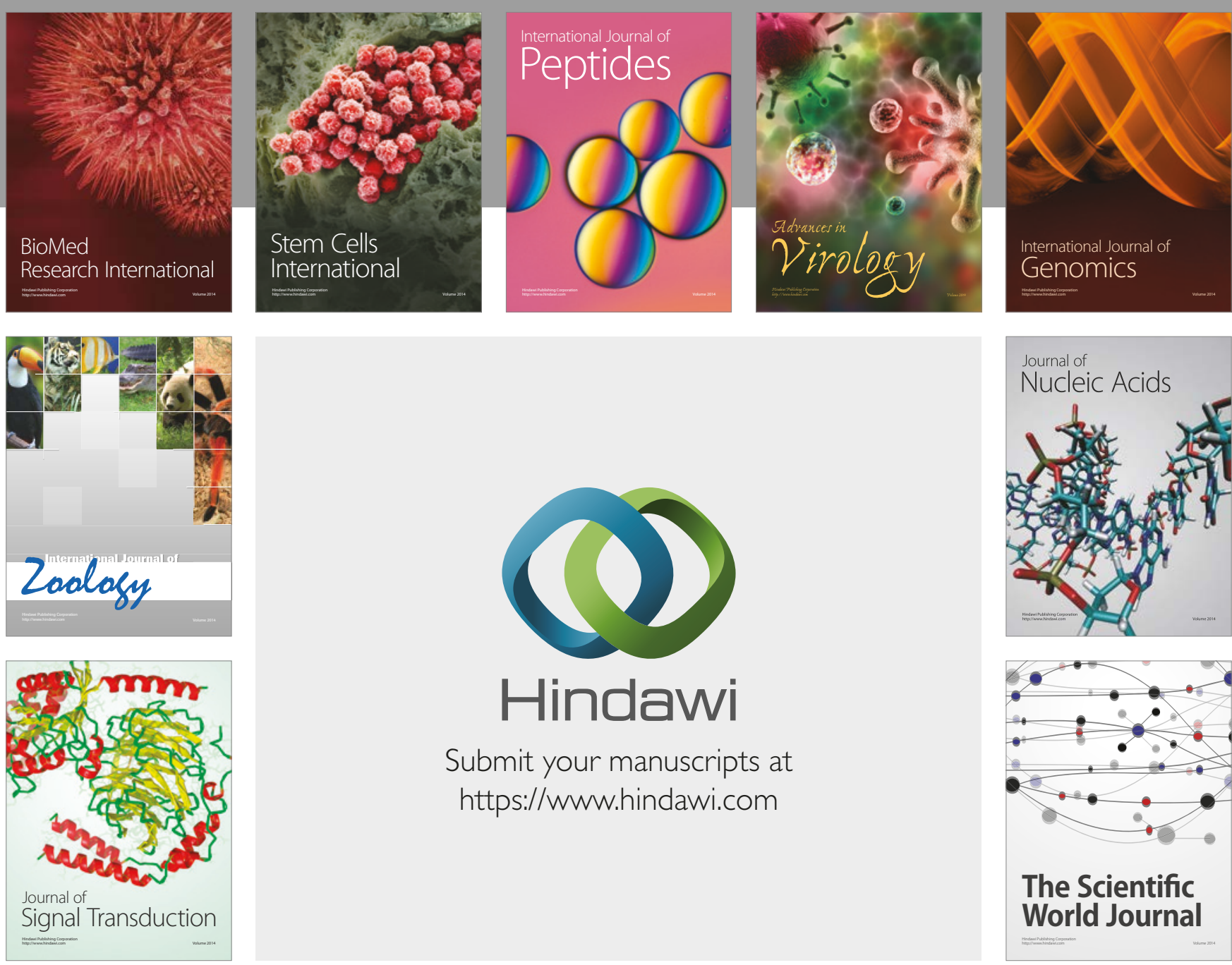

Submit your manuscripts at

https://www.hindawi.com
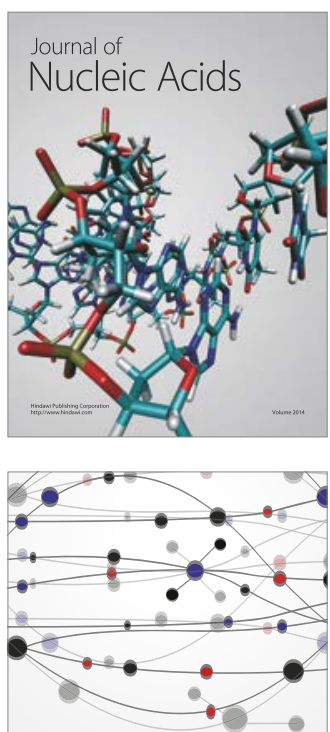

The Scientific World Journal

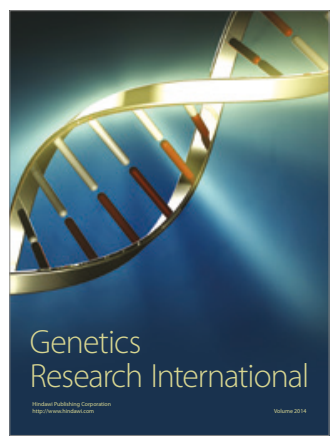

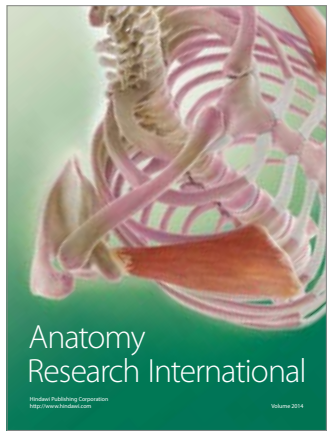

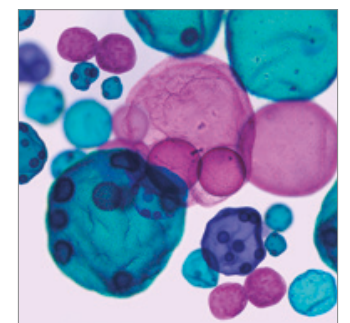

International Journal of Microbiology
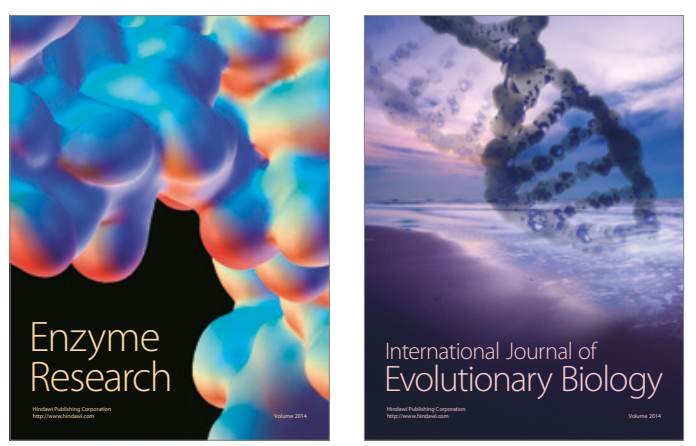
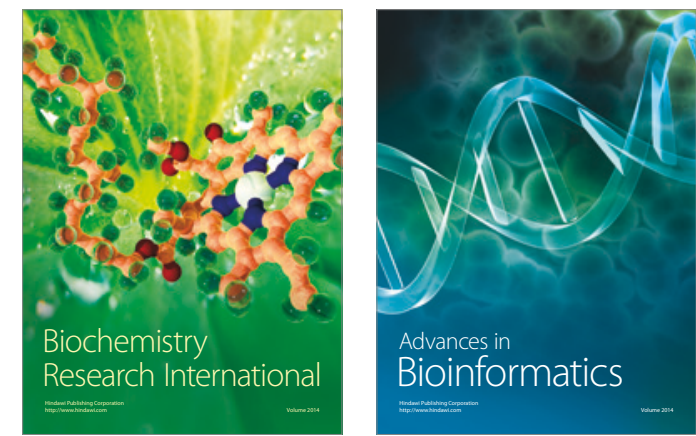

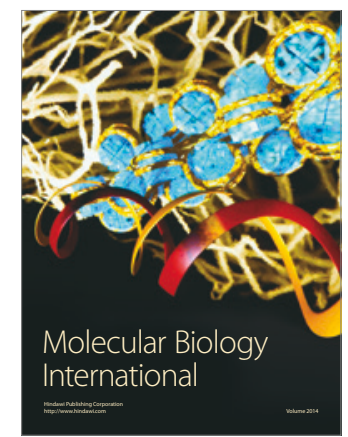

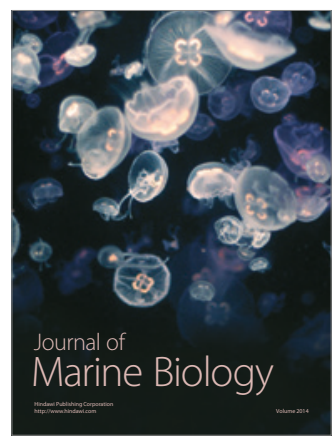

